\title{
ESTIMATION OF GENETIC PARAMETERS FOR SOME PRODUCTIVE AND REPRODUCTIVE TRAITS WITH SIX DIFFERENT MODELS FOR FRIESIAN CATTLE RAISED IN EGYPT
}

\author{
SANAD, SAFAA . S. and M.G . GHARIB \\ Animal production research Institute - ARC, Ministry of Agriculture - Egypt. \\ Email :dr_safaasalah@yahoo.com
}

(Manuscript received 12 April 2017)

\begin{abstract}
$\mathrm{T}$ he main objectives of this study were to detect the most appropriate model that fit the data, that include Lactation period (LP), Total milk yield (TMY), 305day/MY and days open (DO) traits, of Friesian cattle raised in Egypt. Data of 3977 records were collected from 1971 till 1999 (29 years) of cows at Sakha farm. Estimates of genetic parameters (heritability and correlation estimated) by DFREML program resulting from six different statistical models pure examined to determine genetic parameters for productive, reproductive traits and total gain were compared. Six models were used, each have the additive effect of the cow beside the permanent environmental (non- additive genetic) and maternal effect the parameters were estimated by using Variance Component estimation (VCE 6.0) software. Nongenetic factors (fixed effects) had highly significant $(p<0.001)$ for all studied traits. The overall means of LP, TMY, 305-day/MY and DO were 337 day, $4040 \mathrm{Kg}, 3523 \mathrm{Kg}$ and 135 day, respectively. Akaike Information Criterion (AIC) was used to determine the most appropriate model for the studied traits. Model 3 which had additive and maternal effect with their covariance are equal zero, which was the best model. Estimates of direct heritability thatwas relatively low to moderate ranged from $(0.001$ to 0.14$)$, The same trend was observed in the case of maternal heritability were relatively low for studied traits ranged from (0.01 to 0.04$)$. However, The correlation coefficients between all studied traits were highly significant $(p<0.001)$ ranged from $(0.3$ to 0.99$)$. Which means that when the genetic improvement of one of the trait improve the rest of the traits.

key words: Friesian, compared six different models, AIC, Heritability, additive, Maternal effects,.
\end{abstract}

\section{INTRODUCTION}

Milk production has played an important role in the development of human society. It is one of the most economical source of food energy and protein for human being. In addition, dairy cattle will continue to occupy an important position in the world's economy of food production. In order to make fair animal model ranking for identification of genetic merit of individual animals need to develop an operational model closer to the biological one taking into account computational feasibility (Assanet al 2011). 
Animal models utilize all relationships available in a given data set. The search for a suitable statistical model is an important step in the development of genetic improvement Assan et al. (2011). Genetic models, including maternal effects and the covariance of direct and maternal genetic effects, fit data better than the simple additive model, Animal models used to analyze post weaning growth traits in beef cattle typically may not assume maternal effects.

Genetic and phenotypic parameters in quantitative genetics include heritability, genetic and phenotypic correlations, which play a vital role in the formulation of any suitable breeding plan for genetic improvement program (Aynalem, 2006).

The main objectives of the present study were to compare estimates of genetic parameters for LP, TMY, 305-dayMY and DO in Friesian cattle to determine the best model of six multivariate models that can be used as selection criteria of cow.

\section{MATERIALS AND METHODS}

Data used in the present study were conducted from the history sheets of Friesian cows maintained at Sakha farm, belonging to Animal Production Research Institute (APRI), Ministry of Agriculture, Egypt. To determine genetic parameters that effect milk production traits of Friesian cattle in dairy herds. A total number of 3977 lactation records in Sakha herd, during the period from 1971 to 1999 in parities from 1 to 3 in dairy Friesian herd in farm Egypt research station.

\section{Herd management}

Animal nutrition is depends on concentrate feed mixture along with wheat or rice straw in addition to Egyptian clove in winter or clover hay during summer (May to November). As a common practice, milking cows were subjected to machine milking twice. Heifers in farm were served when reaching 18 month of age or $350 \mathrm{~kg}$ of live body weight. Cows were artificially inseminated by using frozen semen from proven sires and pregnancy diagnosis by rectal palpation was performed on 40 day after the last service. The cows were dried off about two months before the next calving. Besides all herd had veterinary consultants for disease management.

\section{Parameter traits studied}

The performance traits under study were milk production traits and reproductive traits Lactation period (LP), Total milk yield (TMY), 305-dayMY and days open( DO) .

\section{Statistical analysis:}

Data was analyses using the general linear model (GLM) procedure (SAS 2003). 
The following statistical mixed model was used:

$Y_{i j k r m}=\mu+S i+P_{j}+S E_{k}+R_{l}+e_{i j k r m}$

where,

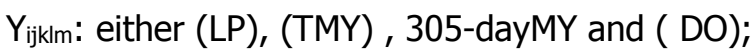

$\mu$ : an underlying constant specific to each trait; $i$ th sire; $P_{j}$ : the fixed effect of $j^{\text {th }}$ parity of calving; $S E_{k}$ :the fixed effect of $k^{\text {th }}$ season of calving; RI: the fixed effect of $\mathrm{I}^{\text {th }}$ year of calving , $e_{i j k r m}=$ random residual assumed to be independent normally distributed with mean zero and variance $\sigma^{2} e$.

Variance and covariance components (direct additive genetic, permanent environmental, error and phenotypic) and heritability's were estimated by restricted maximum likelihood (REML) using the statistical software (VCE 6.0) (Groeneveld et al., 2010):

Six animal models were fitted, for each trait, by ignoring or including maternal genetic effects, permanent environmental maternal effect and covariance between direct the direct and maternal effects..

The following models were used:

Model $1: y=X b+Z_{1} a+e(1)$

Model $2: y=X b+Z_{1} a+Z_{2} c+e(2)$

Model $3: y=X b+Z_{1} a+Z_{3} m+e, \operatorname{Cov}(a, m)=0$ (3)

Model $4: y=X b+Z_{1} a+Z_{3} m+e \operatorname{Cov}(a, m)=A \sigma a, m(4)$

Model $5: y=X b+Z_{1} a+Z_{2} c+Z_{3} m+e \operatorname{Cov}(a, m)=0 A \sigma a m(5)$

Model $6: y=X b+Z_{1} a+Z_{2} c+Z_{3} m+e \operatorname{Cov}(a, m)=A \sigma a, m(6)$

Where $Y$ is the vector of observations $b, a, m, c$ and e are the vectors of fixed effects, direct additive genetic affects, maternal genetic effects, permanent environmental effect and the residual effect, respectively. $X, Z_{a}, Z_{m}$, and $Z_{c}$, are the incidence matrices of fixed effects, direct additive genetic effects, maternal genetic effects and permanent environmental effect of dam. $A$ is the numerator additive genetic relationship matrix between animals and $\operatorname{Cov}(a, m)=\sigma_{a m} A$, where $\sigma_{a m}$ is the covariance between direct and maternal genetic effects, $\sigma^{2}$ a the direct additive genetic variance, $\sigma^{2} \mathrm{~m}$ the maternal genetic variance, $\sigma_{c}^{2}$ the variance of the permanent environmental effect of the dam and $\sigma^{2}$ the variance of the residuals Depending on the model, the log likelihood function was maximized with respect to direct heritability $\left(h^{2} a\right)$, maternal heritability $\left(h^{2} m\right)$, permanent environmental variance of the dam as a proportion of the phenotypic variance $\left(c^{2}\right)$, and the genetic effects as a proportion of the total variance (Cam).

Traditionally log-likelihood ratio tests (LRT) were used to determine the most appropriate model by comparing the differences between log-likelihoods (-2Log $L$ ) to 
a critical value from a chi-square distribution. Using LRT because both models include the same number of parameters. For this reason, the Akaike information criterion (AIC) of Akaike (1973) was computed to rank the models. Let $\mathrm{P}$ denote the number of random (co) variance parameters to be estimated and $-2 \log L$ is the maximum likelihood. Then the Akaike information criterion is defined as: $A I C=-2 L o g L+2 p$. The model yielding the smallest AIC fits the data best.

\section{RESULTS}

Means, standard deviation (SD) and coefficients of variation (CV\%) for some productive and reproductive traits of Friesian cow are given in table 1. Means of LP, TMY, 305-day MY and DO were 337 day, $4040 \mathrm{Kg}, 3523 \mathrm{Kg}$ and 135 day, respectively. These results are higher than reported by Yener et al., (2006) on Frisian cows in Egypt, they found that mean of 305-dayMY and LP was $2806 \mathrm{~kg}$ and 293 day, respectively. While, means of 305-dayMY lower than those obtained by Amr (2013) on Friesian cattle. The present estimate of 305-dayMY was nearest to estimates observed by Ezz El-Arab (2012) on Friesian cows in Egypt. Mean of DO found in the present study was 135.2 day, which is much higher than most values, reported in the literature for the same breed which ranged from 125 and 130.7 day Allam (2011) on Friesian cow in Egypt.

Table 1. Means, minimum (Min), Maximum (Max), standard deviation (SD) and coefficients of variation (CV\%) for some productive and reproductive traits of Friesian cow.

\begin{tabular}{|l|c|c|c|c|c|c|}
\hline Traits & No. of records & Mean & SD & CV\% & Min & Max \\
\hline LP (day) & 3977 & 337 & 111.06 & 31.9 & 100 & 966 \\
\hline TMY $(\mathrm{kg})$ & 3977 & 4040 & 23707 & 41.83 & 174 & 18115 \\
\hline 305 day MY(kg) & 3977 & 3523 & 1804.6 & 34.16 & 174 & 9917 \\
\hline DO(day) & 3977 & 135 & 60.79 & 44.43 & 34 & 316 \\
\hline
\end{tabular}

The values of coefficients of variation (CV\%) for LP, TMY, 305d MY and DO in the present study in table 1 , ranged between 31.9 to 44.43 are lower than those reported by Hammoud (2013) and Mostafa et al. (2013) and higher than those recorded by Sanad Safaa and Afifi (2016).

The relatively high CV\% for some traits in this study may lead to the fact of selection for traits, the differences between the present values of the traits under this study may be due to differences in genotype, number of records used and management. The large CV\% value for milk traits studied reflects a great variation between individuals in such an important traits and higher genetic and phenotypic variations between animals. 


\section{Non genetic parameters:}

The effect of parity had highly significant $(P<0.001)$ effect on all milk production traits under study (table, 2). Similar results agreement with the finding of Gabr (2005) he suggested that the differences in TMY and 305-dayMY among parities were highly significant. Allam (2011) and Amr (2013) found that parity had a highly significant effect on LP. While, results in Tables (2) revealed that TMY and 305day/MY generally, increased with the advancement of parity from the $1^{\text {st }}$ to $3^{\text {th }}$ parity, while DO was decreased with advancement of parity. Faid-Allah (2015) arrived at the same result.

Season of calving had highly significant effect on all milk traits under study $(P<0.001)$ as shown in table 2. Allam (2011) and Sanad and Afify (2016), observed that season of calving had highly significant effect $(P<0.05)$ on LP, TMY and 305day/MY for in cows in Egypt. Gabr (2005) reported that season of calving had highly significant effect on LP and TMY, while no significant effect on 305-day/MY. Awad and Afifi (2003) found that season of calving had significant effect on DO.

The winter and spring had the highest means for TMY and 305 d-MY than the other season (table 2). This result may be due to the climate during winter in Egypt in more suitable and favorable for Friesian cows to give the highest milk production. In the same way Amr (2013), Faid-Allah (2015) and Sanad and Afify (2016).

Also, winter and spring recorded that shortest DO relative to autumn and summer, the same trend was observed by Faid-Allah, 2015. This is the reason because of the relationship between the season and type of food provided to the animal which affects the reproductive performance.

Year of calving had highly significant effect on all milk traits under study $(P<0.001)$ as shown in table 2. Similar of this results recorded by Amr (2013) in Friesian cow, on the other hand, Usman et al. (2012) observed that year of calving was non significant effect on TMY and LP.

The year of calving showed that no clear trend observed in the mean of milk traits over the year study (table 2). These results are in agreement report by Sanad et al. (2013). In this study LP is highly significant $(P<0.01)$ effect by year of calving these results agreed with Sanad and Afify (2016). The different from year to year of calving may be due to the variation in management practices change in herd size from year to another and phenotypic trend. 
1316 ESTIMATION OF GENETIC PARAMETERS FOR SOME PRODUCTIVE AND REPRODUCTIVE TRAITS WITH SIX DIFFERENT MODELS FOR FRIESIAN CATTLE RAISED IN EGYPT

Table 2. Least square means (LSM) and standard Error (SE) for factors affecting Productive and reproductive traits in Friesian cows.

\begin{tabular}{|c|c|c|c|c|c|}
\hline & No. & $\begin{array}{l}\text { LP } \\
\text { (Day) }\end{array}$ & $\begin{array}{l}\text { TMY } \\
(\mathrm{kg})\end{array}$ & $\begin{array}{c}305 \text { day MY } \\
(\mathrm{kg})\end{array}$ & $\begin{array}{l}\text { DO } \\
\text { (day) }\end{array}$ \\
\hline \multicolumn{6}{|l|}{ Parity } \\
\hline 1 & 1767 & $330.2 \pm 2.77 \mathrm{~A}$ & $2991.36 \pm 43.6 \mathrm{~A}$ & $2643.6 \pm 31.06 \mathrm{c}$ & $137.1 \pm 1.55 \mathrm{~A}$ \\
\hline 2 & 1267 & $327.21 \pm 3.19 \mathrm{~A}$ & $3780 \pm 50.17 \quad$ B & $3373.11 \pm 35.7$ B & $134.7 \pm 1.78 \mathrm{~A}$ \\
\hline 3 & 943 & $329.65 \pm 3.65 \mathrm{~A}$ & $4286.5 \pm 57.5 \quad \mathrm{c}$ & $3770.4 \pm 40.9 \mathrm{~A}$ & $125.95 \pm 2.04 \mathrm{~B}$ \\
\hline \multicolumn{6}{|l|}{ Season } \\
\hline Winter & 1264 & $329.3 \pm 3.19 A B$ & $3775.78 \pm 50.15 \mathrm{~A}$ & $3293.59 \pm 35.7 \mathrm{~A}$ & $130.87 \pm 1.78 \mathrm{~A}$ \\
\hline Spring & 1001 & $334.3 \pm 3.55 \mathrm{~A}$ & $3764.8 \pm 55.86$ В & $3273.9 \pm 39.78 \mathrm{~A}$ & $131.2 \pm 1.98 \mathrm{~A}$ \\
\hline Summer & 812 & $322.01 \pm 3.93 B$ & $3448.5 \pm 61.87$ B & $3118.7 \pm 44.06$ & $135.9 \pm 2.19 \mathrm{~A}$ \\
\hline Autumn & 900 & $330.50 \pm 3.72 A$ B & $3754.7 \pm 58.5$ В & $3363.3 \pm 41.69 \mathrm{~A} B$ & $132.3 \pm 2.08 \mathrm{~A}$ \\
\hline \multicolumn{6}{|l|}{ Year } \\
\hline 1971 & 134 & $334.6 \pm 9.5$ & $6159.7 \pm 150.76$ & $5521.5 \pm 107.34$ & $143.3 \pm 5.36$ \\
\hline 1972 & 231 & $343.4 \pm 7.21$ & $6241.6 \pm 113.46$ & $5569.9 \pm 80.88$ & $147.5 \pm 4.03$ \\
\hline 1973 & 257 & $362.7 \pm 6.75$ & $6558.2 \pm 106.19$ & $5550.7 \pm 75.62$ & $136.2 \pm 3.78$ \\
\hline 1974 & 276 & $378.5 \pm 6.52$ & $6937.6 \pm 102.57$ & $5749.1 \pm 73.03$ & $137.9 \pm 3.65$ \\
\hline 1975 & 204 & $364.98 \pm 7.5$ & $6609.6 \pm 118.89$ & $5364 \pm 84.65$ & $150.3 \pm 4.23$ \\
\hline 1976 & 238 & $335.9 \pm 9.97$ & $5235.9 \pm 109.68$ & $4447.6 \pm 78.1$ & $134.9 \pm 3.89$ \\
\hline 1977 & 217 & $362.7 \pm 7.3$ & $4141.3 \pm 115.05$ & $3661.52 \pm 81.9$ & $136.1 \pm 4.09$ \\
\hline 1978 & 233 & $355.4 \pm 7.08$ & $3357.7 \pm 111.2$ & $2876.3 \pm 79.2$ & $133.1 \pm 3.95$ \\
\hline 1979 & 205 & $315.01 \pm 7.52$ & $3244.6 \pm 118.4$ & $2973.1 \pm 84.27$ & $126.9 \pm 4.21$ \\
\hline 1980 & 179 & $321.4 \pm 8.04$ & $3022.8 \pm 126.6$ & $2798.7 \pm 90.12$ & $128.5 \pm 4.49$ \\
\hline 1981 & 139 & $334.1 \pm 9.1$ & $2859.0 \pm 143.9$ & $2548.3 \pm 102.49$ & $128.1 \pm 5.12$ \\
\hline 1982 & 85 & $336.1 \pm 1.66$ & $3502.2 \pm 183.5$ & $3157.1 \pm 130.69$ & $127.8 \pm 6.5$ \\
\hline 1983 & 78 & $399.1 \pm 12.18$ & $4197.6 \pm 191.8$ & $3519.3 \pm 136.55$ & $136.6 \pm 6.8$ \\
\hline 1984 & 88 & $366.9 \pm 11.4$ & $3783.9 \pm 180.9$ & $3268.7 \pm 128.86$ & $137.2 \pm 6.4$ \\
\hline 1985 & 86 & $311.9 \pm 11.6$ & $3292 \pm 182.33$ & $3005.3 \pm 129.82$ & $136.8 \pm 6.48$ \\
\hline 1986 & 110 & $351.8 \pm 10.3$ & $3194.7 \pm 161.82$ & $2808.8 \pm 115.22$ & $131.9 \pm 5.75$ \\
\hline 1987 & 120 & $330.9 \pm 9.8$ & $2776.7 \pm 154.9$ & $2493.3 \pm 110.28$ & $128.6 \pm 5.51$ \\
\hline 1988 & 114 & $312.8 \pm 10.12$ & $2400.7 \pm 159.3$ & $2129.8 \pm 113.39$ & $139.6 \pm 5.66$ \\
\hline 1989 & 119 & $323.8 \pm 9.88$ & $2475.5 \pm 155.54$ & $2239.0 \pm 110.75$ & $130.4 \pm 5.53$ \\
\hline 1990 & 81 & $303.9 \pm 11.97$ & $2324.8 \pm 188.39$ & $2055.4 \pm 134.14$ & $132.6 \pm 6.69$ \\
\hline 1991 & 79 & $326.5 \pm 12.12$ & $2387.6 \pm 190.73$ & $2117.9 \pm 135.8$ & $127.0 \pm 6.78$ \\
\hline 1992 & 82 & $319.3 \pm 11.86$ & $2349.9 \pm 186.71$ & $2039.8 \pm 132.9$ & $132.2 \pm 6.64$ \\
\hline 1993 & 68 & $312.6 \pm 13.04$ & $2826.9 \pm 205.25$ & $2623.6 \pm 146.1$ & $126.4 \pm 7.29$ \\
\hline 1994 & 100 & $332.5 \pm 10.8$ & $3308.9 \pm 170.16$ & $2953.8 \pm 121.17$ & $129.6 \pm 6.05$ \\
\hline 1995 & 84 & $291.4 \pm 11.76$ & $2740.9 \pm 185.09$ & $2558.2 \pm 131.79$ & $93.4 \pm 6.58$ \\
\hline 1996 & 117 & $277.6 \pm 9.95$ & $2369.1 \pm 156.6$ & $2314.7 \pm 111.5$ & $140.7 \pm 5.57$ \\
\hline 1997 & 92 & $249.1 \pm 11.27$ & $2040.7 \pm 177.41$ & $2012.3 \pm 126.32$ & $125.7 \pm 6.31$ \\
\hline 1998 & 108 & $312.6 \pm 10.85$ & $3126.4 \pm 162.91$ & $2829.1 \pm 116.0$ & $147.7 \pm 5.79$ \\
\hline 1999 & 53 & $277.02 \pm 14.81$ & $3426.0 \pm 233.13$ & $3421.7 \pm 166.0$ & $117.6 \pm 8.29$ \\
\hline
\end{tabular}




\section{Genetic parameters:}

\section{Heritability:}

Estimates of direct heritability $\left(h^{2} a\right)$ for LP, TMY, 305d-/MY and DO in sex model were shown in table 3 Direct heritability $h^{2} a$ estimates of arranged from 0.003 (DO) to 0.23 (305d-MY). This results agreement with those reported by Awad and Afifi (2003). However, direct heritability $\left(h^{2} a\right)$ estimates of the currrent study were lower than those reported by Hammoud, (2013) and Sanad and Afify, (2016) who reported moderate to high estimates of direct heritability for TMY, 305d-/MY, LP and DO traits. The magnitude of the heritability estimate for days open in the present work was rang from ( 0.001 to 0.02 ) this estimate approaches to those given by M ' hamdi et al. (2010) 0.041 in Holstein. The lowest estimates indicate that this trait is affected mainly by environmental factors through improving feeding and managerial strategy procedures. Model 4. Which ignored maternal effects resulted in generally higher estimates of $\mathrm{h}^{2} \mathrm{a}$ than did the other models table 3.

Maternal heritability $\left(\mathrm{h}^{2} \mathrm{~m}\right)$ for LP, TMY, 305d-MY and DO in sex model shown in table 3 Maternal heritability $\mathrm{h}^{2} \mathrm{~m}$ estimates of arranged from 0.01 to 0.028 (LP) while the rang is from 0.03 to 0.046 (TMY) and 0.015 to 0.031 (305d-MY). Similar results were obtained by Mostafa, et al. (2013), $\mathrm{h}^{2} \mathrm{~m}$ estimates of the current study were lower than those reported by Sanad and Afify, (2016).

Maternal heritability was lower than direct additive heritability in all models.. Acceding to small amount of additive maternal genetic effects for traits studied (table 3) it could be concluded that the additive maternal genetic effects do not seen to make important contributions to the phenotypic variance of milk traits. Probably because the important environmental influence of the dams on their calves is from conception to birth (Mostafa, et al. 2013). 
Table 3. Estimates of covariance components and direct $\left(h^{2} d \pm S E\right)$ and maternal heritability ( $m^{2} \pm S E$ ) as well as direct ( $e^{2} \pm S E$ ), maternal permanent variances ( $\mathrm{c}^{2} \pm \mathrm{SE}$ ) and Akaika information criterian (AIC) ranking of animal models.

\begin{tabular}{|c|c|c|c|c|c|c|c|c|c|c|c|}
\hline Model & Traits & $\sigma 2 a$ & $\sigma^{2} m$ & $02 p e$ & $\sigma^{2} e$ & $\sigma^{2} p$ & $h_{a}$ & $\mathrm{~h}_{\mathrm{m}}$ & $\mathrm{P}_{\mathrm{e} 2}$ & e2 & AIC \\
\hline Model1 & $\begin{array}{l}\text { LP } \\
\text { TM } \\
305 \\
\text { DO }\end{array}$ & $\begin{array}{l}1020 \\
545365 \\
268488 \\
53\end{array}$ & & & $\begin{array}{l}10590 \\
2335347 \\
1185272 \\
3561 \\
\end{array}$ & $\begin{array}{l}11609 \\
2880702 \\
1453760 \\
3614 \\
\end{array}$ & $\begin{array}{l}0.09 \pm 0.01 \\
0.19 \pm 0.02 \\
0.18 \pm 0.02 \\
0.01 \pm 0.008\end{array}$ & & & $\begin{array}{l}0.91 \pm 0.14 \\
0.81 \pm 0.017 \\
0.82 \pm 0.018 \\
0.99 \pm 0.009\end{array}$ & $\begin{array}{l}\text { ô } \\
\frac{1}{2}\end{array}$ \\
\hline Model 2 & $\begin{array}{c}\text { LP } \\
\text { TM } \\
305 \\
\text { DO } \\
\end{array}$ & $\begin{array}{l}718 \\
482265 \\
179389 \\
12 \\
\end{array}$ & & $\begin{array}{l}435.5 \\
55550.8 \\
87961.9 \\
114.8 \\
\end{array}$ & $\begin{array}{l}10428 \\
2329743 \\
1173235 \\
3488 \\
\end{array}$ & $\begin{array}{l}1151 \\
2867559 \\
1440582 \\
3616 \\
\end{array}$ & $\begin{array}{l}0.06 \pm 0.01 \\
0.17 \pm 0.02 \\
0.13 \pm 0.02 \\
0.003 \pm 0.003\end{array}$ & & $\begin{array}{l}0.03 \pm 0.008 \\
0.02 \pm 0.008 \\
0.06 \pm 0.016 \\
0.03 \pm 0.010\end{array}$ & $\begin{array}{l}0.90 \pm 0.01 \\
0.81 \pm 0.014 \\
0.81 \pm 0.015 \\
0.96 \pm 0.01\end{array}$ & 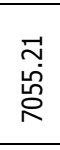 \\
\hline Model 3 & $\begin{array}{l}\text { LP } \\
\text { TM } \\
305 \\
\text { DO }\end{array}$ & $\begin{array}{l}580 \\
382265 \\
179389 \\
2 \\
\end{array}$ & $\begin{array}{l}109.6 \\
99851.6 \\
49477.3 \\
39.5 \\
\end{array}$ & & $\begin{array}{l}10843 \\
2344720 \\
1185895 \\
3533 \\
\end{array}$ & $\begin{array}{l}11533 \\
2833766 \\
1432934 \\
3575 \\
\end{array}$ & $\begin{array}{l}0.05 \pm 0.002 \\
0.14 \pm 0.01 \\
0.14 \pm 0.01 \\
0.001 \pm 0.001\end{array}$ & $\begin{array}{l}0.01 \pm 0.001 \\
0.04 \pm 0.002 \\
0.04 \pm 0.004 \\
0.01 \pm 0.002 \\
\end{array}$ & & $\begin{array}{l}0.99 \pm 0.009 \\
0.82 \pm 0.009 \\
0.82 \pm 0.012 \\
0.99 \pm 0.002\end{array}$ & 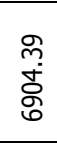 \\
\hline Model 4 & $\begin{array}{c}\text { LP } \\
\text { TM } \\
305 \\
\text { DO } \\
\end{array}$ & $\begin{array}{l}1199 \\
556299 \\
314214 \\
54 \\
\end{array}$ & $\begin{array}{l}316 \\
83776 \\
42260 \\
111 \\
\end{array}$ & & $\begin{array}{l}10482 \\
2323267 \\
1174001 \\
3513 \\
\end{array}$ & $\begin{array}{l}11203 \\
2786107 \\
1381856 \\
3552 \\
\end{array}$ & $\begin{array}{l}0.11 \pm 0.016 \\
0.20 \pm 0.019 \\
0.23 \pm 0.023 \\
0.02 \pm 0.008\end{array}$ & $\begin{array}{l}0.028 \pm 0.014 \\
0.03 \pm 0.019 \\
0.031 \pm 0.019 \\
0.031 \pm 0.012\end{array}$ & & $\begin{array}{l}0.94 \pm 0.016 \\
0.83 \pm 0.019 \\
0.85 \pm 0.025 \\
0.99 \pm 0.008\end{array}$ & 瓷 \\
\hline Model 5 & $\begin{array}{c}\text { LP } \\
\text { TM } \\
305 \\
\text { DO } \\
\end{array}$ & $\begin{array}{l}424 \\
351525 \\
129570 \\
9 \\
\end{array}$ & $\begin{array}{l}141.0 \\
92222.1 \\
20790.4 \\
20.1 \\
\end{array}$ & $\begin{array}{l}566 \\
87861 \\
110118 \\
87 \\
\end{array}$ & $\begin{array}{l}10470 \\
2326777 \\
1172422 \\
3510 \\
\end{array}$ & $\begin{array}{l}11602 \\
2858385 \\
1432901 \\
3626 \\
\end{array}$ & $\begin{array}{l}0.09 \pm 0.004 \\
0.12 \pm 0.010 \\
0.09 \pm 0.009 \\
0.002 \pm 0.001\end{array}$ & $\begin{array}{l}0.012 \pm 0.002 \\
0.032 \pm 0.005 \\
0.015 \pm 0.004 \\
0.006 \pm 0.002\end{array}$ & $\begin{array}{l}0.05 \pm 0.005 \\
0.03 \pm 0.004 \\
0.08 \pm 0.007 \\
0.02 \pm 0.005\end{array}$ & $\begin{array}{l}0.90 \pm 0.007 \\
0.81 \pm 0.01 \\
0.82 \pm 0.01 \\
0.97 \pm 0.005\end{array}$ & $\begin{array}{l}\widehat{\sigma} \\
\text { ָू } \\
\text { م }\end{array}$ \\
\hline Model 6 & $\begin{array}{c}\text { LP } \\
\text { TM } \\
305 \\
\text { DO }\end{array}$ & $\begin{array}{l}541 \\
333642 \\
170910 \\
36 \\
\end{array}$ & $\begin{array}{l}225 \\
128743 \\
22363 \\
65 \\
\end{array}$ & $\begin{array}{l}427 \\
127573 \\
101658 \\
62\end{array}$ & $\begin{array}{l}10454 \\
2315799 \\
1169366 \\
3458 \\
\end{array}$ & $\begin{array}{l}11400 \\
2790017 \\
1408892 \\
3562 \\
\end{array}$ & $\begin{array}{l}0.03 \pm 0.008 \\
0.12 \pm 0.015 \\
0.12 \pm 0.018 \\
0.01 \pm 0.005\end{array}$ & $\begin{array}{l}0.019 \pm 0.009 \\
0.046 \pm 0.015 \\
0.016 \pm 0.005 \\
0.018 \pm 0.008\end{array}$ & $\begin{array}{l}0.04 \pm 0.001 \\
0.05 \pm 0.007 \\
0.07 \pm 0.012 \\
0.02 \pm 0.004\end{array}$ & $\begin{array}{l}0.92 \pm 0.008 \\
0.83 \pm 0.015 \\
0.83 \pm 0.016 \\
0.97 \pm 0.005\end{array}$ & $\begin{array}{l}\dot{\sim} \\
\dot{\sim} \\
\dot{\mathrm{H}}\end{array}$ \\
\hline
\end{tabular}

$\sigma^{2}{ }_{a}$-additive direct genetic variance; $\sigma^{2}$-additive maternal genetic variance; $\sigma^{2}$ pe-permanent environmental maternal variance ; $\sigma^{2}$-phenotypic variance-sum of variance and covariance components; $\sigma^{2}$-error variance; $\mathrm{h}^{2}{ }_{\mathrm{a}}$-direct heritability; $\mathrm{h}^{2}$-maternal heritability; $\mathrm{AIC}=-2(\mathrm{Log} . \mathrm{L})+2 \mathrm{P}$. 


\section{Permanent environmental $\left(\mathrm{Pe}^{2}\right)$ :}

Permanent environmental Pe2 estimates of arranged from 0.02 (DO and TMY) to 0.08 (305d/MY). Were lower than those reported by Khattab et al. (2005) working on Holstein Friesian cattle in Egypt.Found that $\mathrm{Pe}^{2}$ estimates for $305 \mathrm{~d} / \mathrm{MY}$ and AFC were 0.06 and 0.11 , respectively .

This result was in agreement with those reported by Awad and Afifi (2003). Fitting maternal permanent environmental variance $\mathrm{Pe}^{2}$ in Model two while inclusion of maternal genetic effects (Model 3-6) showed further reduction in $\mathrm{h}^{2} \mathrm{a}$ for which there is negligible difference in $\mathrm{h} 2 \mathrm{a}$ of the other models within each trait in table 3.

\section{Ranking the Models}

Assumption was that model 6 is the appropriate model because none of the parameters of interest in the model were restricted.

Model (3) was sufficient to explain the variation in the data. It is notable that data structure has a great impact on the accuracy of maternal effects estimation Gad (2014) indicated that. Akaike Information Criterion (AIC) was used to determine the most appropriate model for the studied traits. Model 3 which had additive and maternal effect with their covariance are equal zero, which was the best model. Gad (2014) indicated that a large data set and several well-linked generations of records and many relationships between relatives related to the mother were needed to accurately separated maternal permanent environmental effects from combined and direct effects.

\section{Genetic correlation:}

Correlation coefficients among traits studied are showed in table (4). The additive genetic correlation $\left(\mathrm{r}_{\mathrm{a}}\right)$ between traits studied was positive and ranged from 0.31 to 0.99 . Generally additive genetic correlation was higher than the corresponding maternal genetic ones. Whereas those additive genetic correlations between traits studied were less than the respective maternal genetic correlation $\left(r_{m}\right)$. Genetic correlation between DO and each of LP, TMY and 305d/MY were positive.

Table- 4. Correlation Coefficient between of traits study in Friesian cattle (Model 3)

\begin{tabular}{|l|l|l|l|}
\hline & $r_{a}$ & $r_{M}$ & $r_{P}$ \\
\hline LP* TMY & 0.99 & 0.95 & 0.69 \\
\hline LP* 305 & 0.99 & 0.83 & 0.39 \\
\hline LP*DO & 0.31 & 0.87 & 0.24 \\
\hline TMY* 305 & 0.99 & 0.61 & 0.76 \\
\hline TMY*DO & 0.31 & 0.73 & 0.17 \\
\hline 305*DO & 0.32 & 0.92 & 0.09 \\
\hline
\end{tabular}


It is concluded from the present study that short DO will increase milk production. The positive genetic correlations between traits especially productive ones clarified that these traits could be improved simultaneously via multi-trait selection breeding program. Hammoud (2013) obtained negative genetic correlation in Holstein cows $\left(r_{g}=-0.31\right)$ between TMY and DO; positive genetic correlation $\left(r_{g}=0.35\right)$ between TMY and 305/dMY; between LP and TMY $\left(r_{g}=0.31\right)$, 305-dMY $\left(r_{g}=0.29\right)$; positive genetic correlations between DO and 305-dMY $\left(r_{g}=0.32\right)$, LP $\left(r_{g}=0.34\right)$. Faid-Allah (2015) obtained positive genetic correlation ( $r_{g}=0.406$ and 0.413 ) between 305/dMY and both of LP and $\mathrm{DO} ;\left(r_{g}=0.882\right)$. In addition, the strong positive phenotypic correlation was observed between LP*TMY, LP*305, LP*DO, TMY*305, TMY*DO and $305 * \mathrm{DO}$ were $0.69,0.39,0.2,0.75,0.16$ and 0.09 , respectively in table 4 . Phenotypic correlation $\left(r_{p}\right)$ were lower than the corresponding direct additive genetic ones which agreed in general with findings obtained elsewhere (Sanad and Afify, 2016).

\section{CONCLUSION}

Selection of the correct model is very important, because the more complex the model, the larger the time needed for solution. However, increasing the accuracy of estimation by adding more effects to the model that better explain the data would be more important than saving the time needed for solution. Full animal model generally had higher estimates of heritability and genetic correlation for LP, TMY, 305day/MY and DO. In addition, the model three better fit with the full animal model.

Our results indicate the importance of direct genetic and environmental effects rather than maternal genetic in productive and reproductive traits for Friesian cows raised in Egypt. Therefore, selection based on direct genetic effects would be more effective and using the relative higher estimate for maternal genetic component show model three to be better than other models with maternal genetic effects,

The low heritability estimate for days open in this study indicates that there is low additive genetic variance in the study population. It indicates that the observed phenotypic variation is largely attributable to environmental effect.

\section{ACKNOWLEDGMENT}

The researchers would like to thank and acknowledgements are extended to Nazem A. Shalaby Professor Dr of Animal breeding, Mansoura Faculty of Agriculture to assist us in analyzing the data. 


\section{REFERENCES}

1. Akaike. 1973. Information Theory and an Extension of the Maximum Likelihood principle in $2^{\text {nd }}$ International symposium on information Theory (B.N.Petrov and F.Csaki,eds.). AkademiaiKiado, Budapest.

2. Allam, A.A.F. 2011. Evaluation of productive and reproductive performance of Friesian cattle under Egyptian condition. M.Sc. Thesis, Fac. of Agric. Damanhur Univ.Egypt.

3. Amr. M. A. 2013. Evaluation of performance of some dairy herds in Egypt PhD .Thesis Face .Agaric . Alexandria Universe . Egypt

4. Assan, V.Masache A, Tambe G. 2011. Impact of maternal effects on ranking of animal Models in genetic parameter estimation for 18-Months weight in indigenustui cattle of Zimbabwe volume - 1 ,Issue . 2231-4490.

5. Awad, Set El-Habaeib and Afify. 2003. relationships between milk production and some reproductive performance in Friesian cows Egypt .J .Appl.Sci , 18(6) 2003 .

6. Aynalem H. 2006. Genetic and Economic Analysis of Ethiopian Boran Cattle and their Crosses with Holstein Friesian in Central Ethiopia.A Ph.D. Thesis division of dairy cattle breeding National dairy research institute, Karnal132001 (Haryana), India.pp.65-146.

7. Ezz-El-Arab, W.F.A. 2012. Effect of steaming up on some productive and reproductive traits in dairy cows Ph.D. Thesis, Fac of Agric . Alex . univ.Egypt.

8. Faid-Allah, E. 2015. Genetic and Non-Genetic Analysis for Milk Production and Reproductive Traits in Holstein Cattle in Egypt . JITV Vol. 20 No 1 Th. 2015: 10-17

9. Gabr, A.A. 2005. Evaluation of some economic traits of Friesian cows in Egypt .M.Sc. Thesis, Fac . Agric. Mansoura Univ. Egypt.

10. Gad, S.M.A. 2014. Genetic parameters for direct and maternal effects on different Growth rates in Barki Lambs Egyptian J.Anim.Prod . (2014) 51(3) : 172-177 .

11. Groeneveld, E., Kovač, M., Mielenz, N. 2010. VCE 6, Users guide and reference manual, Version 6.0.2.

12. Hammoud, M.H., 2013. Genetic aspects of some firstlactation traits of Holstein cows in Egypt.AlexandriaJournal Agriculture Research, 58: 295-300.

13. Khattab, A.S.,Hulya, A., and Lila Badawy. 2005. Variances of direct and maternal genetic effects for milk yield and age at first calving in a herd of Friesian cattle in Egypt. Arch. Tierz., Dummerstorf 48: 1, 24-31 
14. M.hamdi, N., Aloulou , R., Bouallegue, M., Brar, S.K. and Hamouda, M.B. 2010. Study on functional longevity of Tunisian Holstein dairy cattle using a we bull proportional hazard model. Livestock Sci132: 173-176.

15. Mostafa, M. A.; Enas A. Bader and khattab, A. S. 2013. Variances of direct and maternal genetic effects for milk yield and its composition in a herd of Friesian cows in Egypt J. Animal and Poultry Prod., Mansoura Univ., Vol.4 (8): $493-499$

16. Sanad, Safaa S.; Set-El-Habaieb S. Awad ; Rashwan S.T and Afify A.A. 2013. Genetic evaluation for lifetime milk yield traits of Friesian cattle commercial herd raised in Egypt., Egypt . J. of Apple .Sic ., 28 (6).

17. Sanad. Safaa. S.I and Afify, A.A. 2016. Comparing genetic parameters of Friesian milk production traits in commercial and state farms in Egypt .J.Agricultural Research Center. N. 4. 2016.

18. SAS, 2003.User's guide: Statistics, version 9. 4th Ed. SAS Ins., Inc., Cary., NC, USA.

19. Usman T Qureshi MS, Yu Y, Wang Y. 2012. Influence of various environmental factors on dairy production and adaptability of Holstein cattle maintained under tropical and subtropical conditions. Adv Environ Bio 7:366 -372.

20. Yener, S.M.; Akman, N.; Khattab, A.S.and Hussein, A. 2006. Genetic aspects for productive and reproductive traits for Friesian cows in Egypt. 57 th Annual meeting of the European Association for Animal Production, Antalya, Turkey 


\section{تقدير المعالم الور اثية لبعض الصفات الاتتاجية و التناسلية باستخدام 6 نماذج

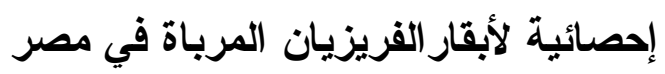

\section{صفاء صلاح سند و محمود غزيب}

معهُ بحوث الانتاج الحيو اني ، مركز البحوث الزراعية ، وزارة الزراعة ، الدقي ، مصر.

تهدف هذه الدراسة الي مقارنة 6 من النماذج الاحصائية التي تتضمن الثأثيرات المباثرة و الامية علي الصفات الانتاجية والتناسلية في الابقار الفريزيان لاختبار أنسب نموذج إحصائي بينهم

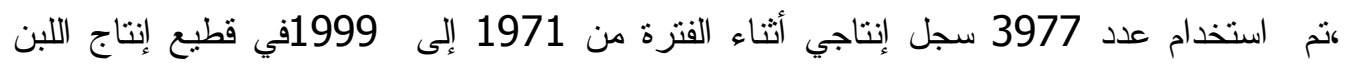

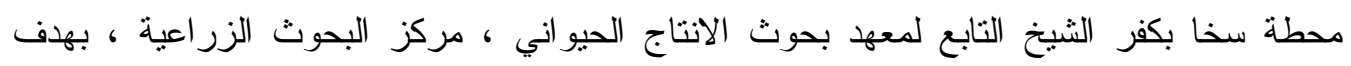

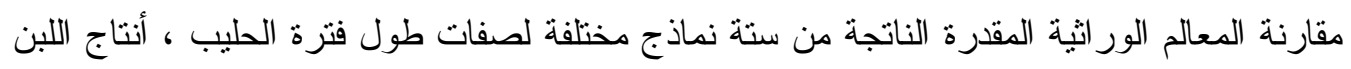
الكلي ، 305 يوم أنتاج اللبن و فترة الايام المفتوحة.

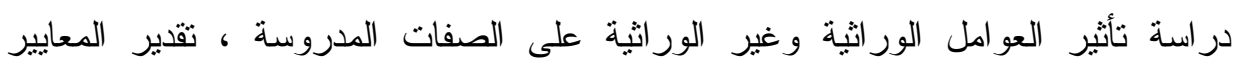

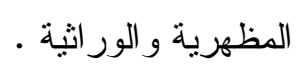

تم حساب المعايير الإحصائية وتحليل التباين باستخدام برنامج SAS (SAS 2003) وتضمن

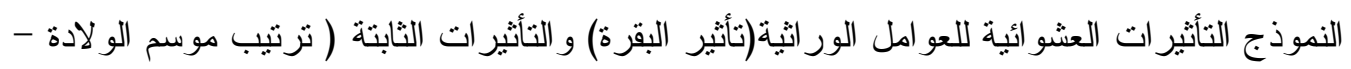

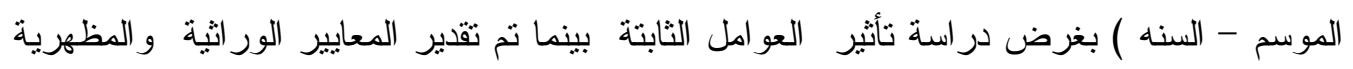
بواسطة برنامج 6.0 VCE المساب المكافئات الوراثية وكذلك الارتباط الوراثي والامي والبئئي و المظهري بين الصفات المختلفة.

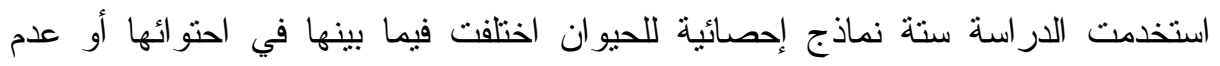

احتو ائها على الثأثير ات الامية ، كما تم استخدام ) Akaike Information Criterion (AIC لتحديد

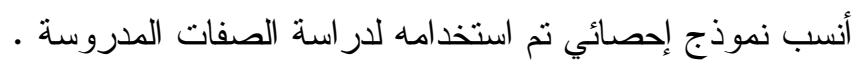

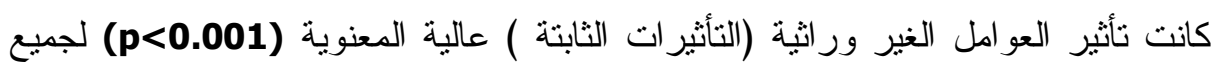
صفات الدراسة.كان منوسط قيم صفات طول فنرة الحليب،أنتاج اللبن الكلي، 305 يوم أنتاج اللبن و والية فترة الايام المفتوحة 337 يومو 4040 كجم و 3523 كجم و 135 يومعلى التوالي لـ وبناء علي لئي قيمة AIC، كان النموذج الثالث هو أنسب نموذج إحصائي بالمقارنة بالنماذج الأخرى المستخدمة.

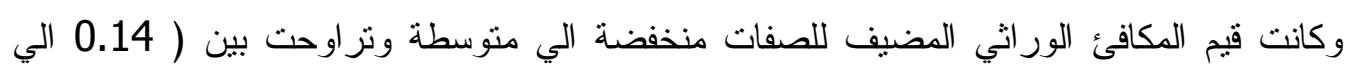

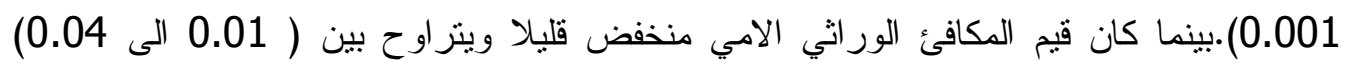
للصفات المدروسة وكانت معاملات الارتباط الوراثي لجميع صفات الدراسة عالئ لاتية المعنوية وتراوحت من +3 .0 إلى 0.99 ـ مما يعني أنه عند التحسين الوراثي لاحد الصفات يؤدي ذلك لكارك 